DOI 10.37882/2500-3682.2021.12.01

\title{
ПОСТМОДЕРНИСТСКАЯ ТРАКТОВКА ЯЗЫКА КАК ОНТОЛОГИЧЕСКОЙ СУЩНОСТИ
}

\section{POSTMODERN INTERPRETATION OF LANGUAGE AS AN ONTOLOGICAL ESSENCE}

E. Agafonov

Summary: Based on the analysis of the ideas of E. Kassir, M. Heidegger, R. Barth, J. Derrida, the article analyzes the rethinking of the direction of philosophical reflection associated with the establishment of linguistic dominant in the analysis of the problems of being. The author shows that in the philosophy of postmodernity, language is understood as an ontological essence, a true world in which the fullness of human existence reveals itself. The ontological approach to understanding the essence of language is considered as the methodological basis of applied research in modern social and humanitarian knowledge.

Keywords: language, being, cognition, meaning, speech, text, information linguistic picture of the world, semantic field, postmodernism.

\author{
Агафонов Евгений Александрович \\ К.ф.н., доцент, Вологодский институт права \\ и экономики ФСИН России \\ evgenagafonov@inbox.ru
}

Аннотация: В статье на основе анализа идей Э. Кассира, М. Хайдеггера, Р. Барта, Ж. Деррида проанализировано переосмысление направленности философской рефлексии, связанное с установлением языковой доминанты в анализе проблем бытия. Автором показано, что в философии постмодерна язык понимается как онтологическая сущность, подлинный мир, в котором обнаруживает себя полнота человеческого бытия. Онтологический подход к пониманию сущности языка рассматривается как методологическая основа прикладных исследований в современном социально-гуманитарном знании.

Ключевые слова: язык, бытие, познание, смысл, речь, текст, информация, языковая картина мира, семантическое поле, постмодернизм.

необходимо лишь расшифровать его, «сконструировав целостное смысловое единство» [2, с. 231], систематическую, завершенную и претендующую на абсолютную истину картину мира.

Можно сказать, что известный гегелевский принцип, провозглашающий тождество бытия и мышления, был распространен и на соотношение мысли и языка, который рассматривался философией сознания как рядовое логическое средство, подвластный человеку инструмент отражения. В философии постмодерна, которая, напротив, отрицала непосредственность связи человека с реальностью «конституирование мира приписывалось уже не трансцендентальной субъективности, а грамматическим структурам языка» [там же, с. 232], который понимается как самоявляющаяся онтологическая сущность.

Еще Э. Кассирер считал язык началом человеческого мышления, через которое бытие обнаруживает, манифестирует себя [3]. По его мнению, семантические значения слов находятся не в предметах, явлениях, а функциональном единстве мышления, связывающем разбросанное во времени и в пространстве содержание. Эта первоначальная функция мышления составляет внутреннюю форму языка, которую невозможно свести только к сознанию, понятию, логике. Она понимается философом как единый принцип систематизации духа, взаимосвязь универсального, общего и конкретно-опытного, частного. Неслучайно, «Философию символических 
форм» Кассирер начинает с анализа язык, который объявляется им фокусом духовного бытия, самостоятельной и изначальной энергией духа [4, с. 101].

Подобный подход к пониманию сущности языка развивает М. Хайдеггер, утверждая, что именно язык дает «слово чему-то существенному в самом бытии» [5, с. 219]. Только через язык истина бытия предпосылает себя мысли, «позволяет воспринять являющееся и пропустить через себя (проработать) воспринятое» [6, с. 261]. Как совершающая речь язык есть существующее указание, знак, фиксирующий и направляющий наши представления. Это не просто средство взаимопонимания, но особый способ бытия, подлинный мир, истинное присутствие.

Таким образом, в современной философии функциональный подход к пониманию сущности языка как результата и средства приспособления человека к окружающему миру сменяется онтологическим, с точки зрения которого необходимым компонентом языка становятся творческие порывы, поиски смысла, стремление к истине. Выражение связности, текучести, многозначности, хаотической неустойчивости и отсутствия жесткого детерминизма явлений бытия «присутствует в языке-посреднике - представителе человека в мире» [7, с. 286]. В языке каждый индивид, преодолевая ограниченность своей частной жизни, реализует незримый диалог с современниками, предками и потомками. Этот вербальный «мост», объединяющий поколения и культуры, и создает человеческий «космос» как некое упорядоченное из единого центра целое.

Только в языке возможен образ мира или его отдельных фрагментов. В нем «опрокинута», максимально проявляется сама натура человека. При этом речь здесь идет не только о способности мыслить. Так, на ранних стадиях развития социальное взаимодействие, в том числе и языковое, не имело однозначного рационально-понятийного смысла. Сегодня известно, что попытки преодоления различных патологий органов, связанных с речевой функцией, выявляют такие значимые предпосылки и элементы вербального, как оживление устоявшихся речевых стереотипов, «оречевление» значимых ситуаций. В современной науке широко используются приемы альтернативной дискурсивной практики, «олитературивания», конвенции, допущения, символы и метафоры, которые изначально были присущи лишь гуманитарному познанию.

Вся эта диалогическая глубина жизненных проявлений «дает носителю языка возможность гибко реагировать на изменения в мире... по типу функциональной зависимости далекой от однозначности» [7, с. 289], показывает неполноту, незавершенность мироздания. Если философия рационализма и позитивизма стремилась к освобождению мысли от обыденных стереотипов и расплывчатых значений, то хайдеггеровская онтологическая традиция «напротив, предполагает... полное погружение в язык и исконную языковую метафоричность как пристанище бытия и всякой правомочной мысли о бытии» [8, с. 175]. Язык как «дом бытия» хранит существование человека в мире, а представляющая присутствующее бытие речь становится информацией о событии.

Так, анализируя творчество Флобера, Р. Барт показывает, что именно разнообразные языки культуры, «социолекты», а порой даже их отсутствие создают полноту дискурса, раскрывают многоголосую реальность. Поэтому справедливым представляется тезис мыслителя о том, что «язык - это область, которой ничто не внеположно» [9, с. 522], за его пределами нет обитаемого человеком бытия. И сам говорящий (автор), и текст являются продуктом языка, который не позволяет, а заставляет сказать. Древние греки прислушивались к звукам окружающего мира, пытаясь различить разлитое в них содержание. Для современного человека гул языка раскрывает «трепещущий в нем смысл» [10, с. 544]. По мнению Барта, только язык составляет человеческую природу. В речевой деятельности, тексте людьми конструируется реальность и осуществляется полнота человеческого бытия.

Можно сказать, что Ж. Деррида выстраивает свои взгляды на основе борьбы с метафизикой, что также обуславливает особую роль языковой проблематики в его творчестве. Язык рассматривается им как изначально заданная система устойчивых категориальных расчленений, которые организуют процесс мышления, образуя условия означения, возможность смыслополагания. Деконструкция как особый метод есть «выявление меры самостоятельности языка со всеми его концептуальными расчленениями и всей его метафоричностью» [8, с. 177]. Поэтому он призывает к обнаружению внутренней противоречивости, непоследовательности и открытости текста, пересмотру устоявшихся смыслов.

Итак, человек с точки зрения постмодернистской методологии существует только в языке, а, значит, не может оказаться вне текста. Задачей сознания становится не интерпретация, истолкование, а разрушение кажущейся целостности текста, деконструкция как отказ от претензии на истину и поиска полноты смысла. Единственной истинной реальностью становится речевой акт. На основе отказа от мистифицированной идеи трансцендентального означаемого как внетекстуального онтологического референта, подтверждающего адекватность смысла, постметафизической философией формулируется принцип «тотальности языка - т. е. понимание языковой реальности как исчерпывающе самодостаточной и не нуждающейся ни в каком внеязыковом гаранте» [11, c. 668]. Таким образом, наличное бытие обретает толь- 
ко существующее в тексте содержание. В методологии постмодернизма слово является механизмом и материалом конструирования реальности.

Онтологический подход к пониманию сущности языка, сформировавшийся в рамках неклассической эпистемологии, сегодня становится методологической основой прикладных исследований в различных областях социально-гуманитарного познания. Наряду с такими понятиями, как «язык», «речь», «слово» одной из базовых категорий современной лингвистики становится «языковая картина мира». Нельзя не согласиться с тем, что данное понятие не терминологично и употребляется как некая архетипическая метафора, раскрывающая основы языка и содержание, «определяющее его сущность «сейчас» $[12$, с. 89]. Выражение «картина мира» активно использовалось еще М. Хайдеггером в рамках его программы «деструкции» традиционной метафизики. По мысли философа, мир, понятый в смысле картины, возможен там, где «к сущему в целом приступают как к тому, на что человек нацелен» [13, с. 49], хочет преподнести себе, «пред-ставить» перед собой.

Одним из важнейших элементов языковой картины мира является семантическое поле, которое представляет «структурную организацию окружающего мира, вербализированную посредством языка» [14, с. 232]. В языкознании использование данного понятия рассматривается как метод установления связей между явлениями языковой действительности, раскрывающий внутреннюю форму языка. Как философская категория семантическое поле становится способом выявления дискурсивной репрезентации «оязыковленной» реальности.

В современной когнитивной лингвистике особую актуальность приобретает понятие «информация» как содержание сообщения или фрагмент знания, представляемого языковыми формами. «Инфосферу» рассматривают в качестве специфической, отличной от природного мира человеческой реальности, объединяющей в себе материальное и идеальное, субъективное и объективное бытие. Сегодня на смену атрибутивному и функциональному подходу к пониманию информации также приходит онтологический подход, берущий за основу языковые аспекты существования данного явления. Так, утверждается, что «понимание природы информации опосредовано значениями языковых выражений» [15, с. 17], определяемых языковой картиной мира.

Таким образом, можно утверждать, что переосмысление направленности философской рефлексии, получившее название «лингвистического поворота», было обусловлено не бурным развитием позитивного естественнонаучного знания и, как следствие, исчезновением специфического предмета философии, а установлением языковой доминанты в анализе проблем бытия.

\section{ЛИТЕРАТУРА}

1. Аристотель. Метафизика // Антология мировой философии. В 4-х томах. Т. 1. Философия древности и средневековья. Ч. 1. М.: Мысль, 1969 (АН СССР. Философское наследие). С. 408-428.

2. Румянцева Т.Г. Классика - неклассика - постнеклассика // Новейший философский словарь. Постмодернизм / Главный научный редактор и составитель А.А. Грицанов. Минск: Современный литератор, 2007. С. 229-234.

3. Кассирер Э. Познание и действительность. Понятие о субстанции и понятие о функции. СПб.: изд. “Шиповник”, 1912. 454 с.

4. Кассирер Э. Философия символических форм. Том 1. Язык. М.; СПб.: Ун. книга, 2002. 272 с.

5. Хайдеггер М. Письмо о гуманизме // Хайдеггер М. Время и бытие: Статьи и выступления. М.: Республика, 1993 . С $192-220$.

6. Хайдеггер М. Путь к языку // Хайдеггер М. Время и бытие: Статьи и выступления. М.: Республика, 1993. С. 259-273.

7. Киященко Л.П. Диалог внутри языка. Рационален ли язык? // Философия науки. 1995. № 1. С. 285-299.

8. Автономова Н.С. Познание и перевод. Опыты философии языка. М.: Российская политическая энциклопедия (РОССПЭН), 2008. 704 с. (Humanitas).

9. Барт Р. Разделение языков // Барт Р. Избранные работы: Семиотика: Поэтика: Пер. с фр. / Сост., общ. ред. и вступ. ст. Г.К. Косикова. М.: Прогресс, 1989. С. $519-534$.

10. Барт Р. Гул языка // Барт Р. Избранные работы: Семиотика: Поэтика: Пер. с фр. / Сост., общ. ред. и вступ. ст. Г. К. Косикова. М.: Прогресс, 1989. С. $541-544$.

11. Грицанов А.А. Трансцендентальное означаемое // Новейший философский словарь. Постмодернизм / Главный научный редактор и составитель А.А. Грицанов. Минск: Современный литератор, 2007. С. 668-669.

12. Воротников Ю.Л. «ЯЗыковая картина мира»: трактовка понятия // Знание. Понимание. Умение. 2006. № 2. С. 88-90.

13. Хайдеггер М. Время картины мира // Хайдеггер М. Время и бытие: Статьи и выступления. М.: Республика, 1993. С. 41-62.

14. Рубцов И.Н. Семантические поля как способ реализации языковых картин мира // С. 231-236.

15. Манаенко Г.Н. Информация в языке и по данным языка // Актуальные проблемы филологии и педагогической лингвистики. 2015 . № 2. С. 12-20.

(с) Агафонов Евгений Александрович (evgenagafonov@inbox.ru) 